\title{
Features of the Twentieth-Century Novel
}

\section{Dr. Ibrahim Yêkini, Dr. Franck MOUSTAPHA, Dr. Hergie A. Seguedeme}

Universitéd'Abomey-Calavi

\begin{abstract}
This paper highlights the new mission of novelists in the twentieth century in Europe, sheds more light on the break with entertainment and storytelling of the nineteenth century and analyses the new subject matters of the twentieth century. English authors who may be divided into three generations according to literary periods; the period before 1920, the period between the two World Wars and the period after the World War II.
\end{abstract}

Keywords: moral dilemma, disillusionment, frustration, interior monologues, defect in human nature, Oedipus complex

\section{INTRODUCTION}

The twentieth century broke with the mission of the Victorian novel which is storytelling and entertainment it rather focuses on character to unravel the intricate web of thoughts and feelings that activate the individual. Many novels were mainly concerned with propaganda and social issues.

Early in the twentieth century the novel was impacted by the works of some prominent nineteenthcentury writers such as the Russians Feodor Dostoevsky and Leo Tolstory, and the French novelists Honoré de Balzac, Emile Zola, Guy de Maupassant, and Gustave Flaubert. From them they learned to present people as they usually are: neither wholly good nor bad, but with a mixture of character traits. The older structure of a protagonist and antagonist (or hero and villain) gave way. In modern works, one seldom encounters a villain, pure and simple. Characters struggle with themselves or with a situation, but not with a figure of evil incarnate.

\section{INDIVIDUALS AND MORAL DILEMMA}

Three generations of novels were clearly distinguished during the twentieth century: novels written before 1920; those written between the two world wars; and novels written since World War II. The earliest period was dominated by two figures-Henry James (1843-1916) and Joseph Conrad (18571924); the first was an Anglo American, and the second a Anglo Pole. Henry James's elder brother William was the American father of psychology, and it is scarcely surprising that the novelist focused on finely detailed portraits of individuals. Much of James's work (The American, The Portrait of a Lady, and The Turn of the Screw) was written before the turn of the century. But three masterpieces-The Wings of the Dove, The Ambassadors, and The Golden Bowl-were published in three successive years beginning in 1902. James was especially interested in showing the impact of European culture on wealthy Americans visiting Europe. He skilfully revealed subtle emotions with apparently simple body language and temporal facial expressions which distinguished him-a very different approach from the later stream-of-consciousness technique.

Joseph Conrad, like James, explored individuals who were caught up in a moral dilemma. But his settings and characters were strikingly different from those which James favoured. Many of these novels were set in exotic, faraway locales in the tropics-places he knew well from his years as a sea captain. He experimented constantly with an oblique method of storytelling. Perhaps more than any single writer, Conrad brought to the fore a concern with point of view as a consciously manipulated technique in literature.

Some excellent writers of the period did not reach the pinnacle of achievement of Conrad and James. H. G. Wells (1866-1946), author of some fifty novels, made important experiments in the genre of science fiction--a type of novel which has become immensely popular in our time. Arnold Bennett (1867-1931), a successful journalist, wrote completely realistic stories about the uneventful lives of 


\section{Dr. Ibrahim Yêkini et al.}

ordinary people in Staffordshire, his native county. Writing of a different class of society, John Galsworthy (1867-1933) treated the manners of the wealthy in such works as The Forsyte Saga. Somerset Maugham (1874-1965) expressed early in his career the disillusionment and frustration that were to be leading themes in the next generation. Many critics consider Maugham's Human Bondage (1915) to be his masterpiece. Perhaps the greatest of this secondary group of writers was E. M. Forster (1876-1970), who published his first novel in 1905. Forster's work subtly and ironically explored personal relationships, "that little society" we make for ourselves with our friends. In his greatest (and also his last) novel, A Passage to India (1924), he used the framework of Anglo-Indian relations in the early 1920s to explore the most complex of human relationships: the experiences between individuals of two different cultures and races.

In the period between the wars (1920-1940), three novelists who had written some earlier books matured and produced their most significant work: Virginia Woolf (1882-1941), D. H. Lawrence (1885-1930), and James Joyce (1882-1941). Woolf and Joyce permanently altered novelistic technique through the development of the stream-of-consciousness of writing; Lawrence brought to the novel a fresh strain of vitalism.

\section{INTERIOR MONOLOGUE}

In Woolf's Novel, plot has become only a minor element. It Mrs Dalloway (1925) she subtly probed the thoughts of the title character and her friends on one day in London, giving her readers a remarkable insight into the mental actions and reactions of upper-class Londoners. Woolf's novels are basically a series of interior monologues, or inner soliloquies. Although she was a bold stylistic pioneer, Woolf was never popular with the reading public. But she exerted a major influence on the writers that followed.

James Joyce expanded the technique of interior monologue to a true "stream of consciousness." Recognizing that thoughts in our minds jump at random from one idea to another with extraordinary speed, he attempted faithfully to reproduce the inner consciousness (and sometimes the unconscious) of his characters' minds. Joyce early works, Dubliners and A Portrait of the Artist as a Young Man, were vaguely autobiographical and conventionally organized. But in Ulysses and Finnegans Wake he writes a pure stream of thoughts as they seemingly go leaping or drifting from one idea to another with no logical connection. Superimposed on the actual thoughts is a complex structure of allusion and symbol that affords a universal dimension to the characters.

Strikingly different in subject matter and style from Woolf and Joyce was D. H. Lawrence. The son of a miner, he escaped from the labouring class thoughts a university education. Married to a German, Lawrence supported unpopular ideas by refusing to have anything to do with the military during World War I and by proclaiming that civilization of all types had perverted man's basically noble, primitive nature. Badly treated by the English, Lawrence left England in 1918, never to return. Basically romantic, he wandered the globe, delighting in his nonconformity but increasingly bitter at what regarded as English Puritanism. The titles of Lawrence's principal novels show his fascination for the relationships between men and women whether mother to son or sweetheart to lover) :Sons and Lovers, Women in Love, and Lady Chatterley's Lover.

Many novelists who began to write in the 1930 have come to prominence after World War II, but none has attained the stature of Joyce or Lawrence. William Golding (1911) explored the working of primitive instincts in his striking symbolic novel, Lord of the Flies (1954). More recently, works such as The Inheritors, Pincher Martin, and Free Fall, he has focused on the theme that evil stems from what he considers a fundamental defect in human nature. A similar concern appears in the novels of Graham Greene (1904). Greene has roamed the world from Vietnam to West Africa, Latin America, and Haiti. Using these places as settings for his stories, he shows somewhat seedy protagonists caught up in malignant circumstances. For example, in A Burnt-Out Case (1961) an architect, repelled by modern life, attempts to lose himself in a leper colony deep in Africa and to purge all human desires and adventure/detective stories. In both genres, in the tradition of Conrad, he explores the ambiguities of moral judgment and intensely human crises of faith.

The three early novels of Georges Orwell (10903-1950) grew out of his experiences working with the poor and lonely in the slums of London. Fighting in the Spanish Civil War (1936-1939) on the Republican side, he became sickened by the communist atrocities and returned to England to write his two most powerful books, Animal Farm and Nineteen Eighty-Four. These novels demonstrate the 
inherent desire for power in human beings that always threatens to pervert justice, freedom, and equality. Angus Wilson, on the other hand, has rebelled against what he has called the neo-realism of contemporary fiction; he has insisted that fiction should be fiction, ' 'a created or made up story." One of his most successful books has been the novel Anglo-Saxon Attitudes (1956).

The twentieth century has witnessed the popularization of several new genres of the novel: the detective story, the story of intrigue (or the spy story), and science fiction. The Gothic novel, with origins in the late eighteenth century, was enjoyed a popular renaissance. Many of these novels are deservedly considered "pop" literature, but many of them are superbly crafted and can be accepted as serious literature. Among some literary critics there is the feeling that psychological-social novel introduced by Woolf, Joyce, and Lawrence has runnits course and that a new way of looking at life through storytelling may well be just on the horizon. Perhaps science fiction and fantasy, with their intriguing imaginative experiences, will offer a major new approach. The blending of fiction and nonfiction, as in some "documentary" novels, may continue to grow. In a century of such diverse developments in the novel, the possibilities are as numerous as they are intriguing. As an illustration of a typical modern novel I studied David Herbert Lawrence's Sons and Lovers(1913).

Sons and Lovers (1913) are seen as D.H. Lawrence's transformation of his autobiography into art. Nevertheless it is a fantastic love story which reveals the phase of maturity and a sense of guilty in the author relationship with his father he wrongly hated in his childhood. The novel depicts the sexual and emotional situation the protagonist of the novel, Paul Morel is caught in and his attempt to conceive an identity and a philosophy of his own. Like the author of the novel, Paul Morel believes that the twentieth century British Society made his life unreal and empty through a pernicious class system. Lawrence makes the protagonist of his novel believe in what is natural; nature, its power and beauty. This philosophy is probably one of the reasons of his numerous travels all over the world. His serious exploration of sexuality proves the revolutionary character of his writings, for him, social norms exists but feelings exist as well. Feelings are more important to individuals than laws and principles. Such principles made him one of the most versatile and influential figures of the twentieth century writers. In Sons and Lovers, this reality is stressed as it impacts the inner being of the protagonist and other characters like Gertrude, Paul Morel's mother. Exactly as the same inner conflict in the British conservative Society affected Lawrence's mother. He thinks that his mother was a woman of character and refinement who accepted through love to go into the lower class even if there was no satisfaction in it for her own life, Lawrence writes:

Mrs Morel came of a good old burgher family, famous Independent who had fought with Colonel Hutchinson, and who remained stout Congregationalist...Her father George Coppard was an engineer, proud of his fair skin and blue eyes, but more proud still of his integrity. Gertrude resembled her mother in her small build. But her temper, proud and her unyielding, she had from the Coppard ${ }^{\mathbf{1}}$

Paul's devotion to his mother and early unwilling hatred to his father creates a situation that connects Sons and Loversto its author's e life.

\section{OEDIPUS COMPLEX}

Oedipus complex is a term Sigmund Freud used in his theory of psychosexual stages of development. Kendra cherry (July 2016), writes:

The Oedipal complex is a term used by Sigmund Freud in his theory of theory of psychosexual stages of development to describe a boy's feelings of desire for his mother and jealousy and anger toward his father. Essentially, a boy feels like he is competing with his father for possession of his mother. He views his father as a rival for her attentions and affections. In Psychoanalytic theory, the Oedipus complex refers to the child's desire for sexual involvement with the opposite sex parent, particularly a boy's erotic attention to his mother. Freud suggested that the Oedipus complex played an important role in the phallic stage of psychosexual development. He also believed that successful completion of this stage involved identifying with the same-sex parent which ultimately would lead to developing a mature sexual identity. $^{2}$

${ }^{1}$ D.H. Lawrence. Sons and lovers.London, Penguin Popular classics, 1913. P7. 
In depicting Paul's relation with his mother, Lawrence abundantly uses Oedipus complex. In fact, Paul's love for his mother and the latter's engagement in transference projecting her dissatisfaction with her marriage onto her smothering love for her sons are beyond the conventional concept of mother-son love. Paul dangerously hates his father and even plans his murder to fill in his place around his mother since all his attempts to resist the incestuous desire by transferring them on Miriam and Clara have failed. Fortunately, Baxter Dawes frees him from his complex. By beating Paul savagely for having dated his wife, Dawes unconsciously plays the redemptive role of an imposing father who provides Paul's unconscious desire of punishment for his guilt. The savage beating releases him from his Oedipus complex induces him to overdose his dying mother with morphia to subvert his Oedipus fate by killing his mother instead of his father as Freud explained in The Ego and the $I d$,

The super-ego retains the character of the father, while the more powerful the Oedipus complex was and the more rapidly it succumbed to repression (under the influence of authority, religious teaching, schooling and reading), the stricter will be the domination of the super-ego over the ego later on-in the form of conscience or perhaps of an unconscious sense of guilt. ${ }^{3}$

\section{Treatment OF NATURE}

The $20^{\text {th }}$ century novels explore and expose the shift that characterizes the turn of nineteenth and twentieth centuries. This new movement put emphasis on the importance of the observation of living creatures in their environment. This treatment of the environment, impacted by G.H. Well's The Science of Life ${ }^{4}$ appears in Virginia Woolf's novels.Rachel Cross land in her analysis of Christina Alt, writes:

...the shift in the approach to the life sciences 'resonates beyond the study of nature to a change in outlook that characterized Virginia Woolf's literary modernism'. Alt seeks to reassess Woolf's links to the study of nature by focusing on the contemporary understanding thereof as demonstrated by late nineteenth- and early twentieth-century books and articles addressing this changing branch of science. By so doing Alt is able to reposition Woolf away from the anticipatory role of protoeco-feminist which has recently been assigned to her and to re-immerse her ideas within their contemporary context. Virginia Woolf and the Study of Nature ${ }^{6} .$. focuses on the life sciences themselves, exploring the rapid rise of taxonomy during the nineteenth century and the subsequent rejection of this approach in the early years of the twentieth century. Alt demonstrates that the rise of ethology at the turn of the century can be seen as a 'revival' of an earlier approach fostered in particular by Gilbert White at the end of the eighteenth century, and explores the overlap between original work and popular science in the early stages of the development of the fields of ethology and ecology (61). Alt's emphasis in these chapters is on the ways in which developments in the life sciences changed the manner in which nature was perceived by scientists and the general public alike, in particular in terms of the movement towards the observation of organisms within their natural environment. ${ }^{5}$

The connection between the nineteenth century and the twentieth depiction of arts and sciences is conceived as the objectives of many writers within the field of literature. David Herbert Lawrence sided with the same approach in his Sons and Lovers. The novel exposes many descriptions of the natural environment with characters experiencing moments of romantic transcendence. With concrete and vivid pictures of the nature, Lawrence frequently eroticizes this description to highlight sexual energy and to provoke the moral code of his time and its repression.

\footnotetext{
${ }^{2}$ Kendra cherry, What is an Oedipus complex? https//www.verywzll, July 2016.

3

3 Freud, S.The Ego and the id. The Hogarth Press Ltd. London, 1949

${ }^{4}$ G. P. Wells The Science of Life. 1931New York: Barnes and Noble, 2003.

${ }^{5}$ Christina Alt, Virginia Woolf and the Study of Nature.Cambridge: Cambridge University Press, 2010.
} 


\section{GEORGE ORWELL AND THE ANTI-COMMUNIST DEPICTION}

Nineteen Eighty-Four is a wonderful social and political satire of the twentieth century Russian and Italian communist regimes. George Orwell wrote it after Animal Farm which was an allegory of Russian revolution and an analogy of his previous novel. Thomas Pynchon wrote:

Although Big Brother's face certainly is Stalin's, just as the despised Party heretic Emmanuel Goldstein's face is Trotsky's, the two do not quit line up with their models as neatly as Napoleon and Snowball did in Animal Farm. This did not keep the book from being marketed in the United States as a sort of anti-communist tract. It arrived in the thick of the McCarthy era, when «communism» was damned officially as a monolithic, worldwide menace, and there was no point in even distinguishing between Stalin and Trotsky, any more than for shepherds to be instructing sheep in the nuances of wolf recognition. ${ }^{6}$

The novel alluds to the political situation prevailing in Asia under the authority of Stalin and highlights the communist strategy of ideological enforcement and psychological control by brainwashing opposants through a series of techniques inspired by the works of I. P. Pavlov. As Pavlov trained dogs to salivate in response on cue, the Soviet politicians conditioned citizens and puppets communist states like China and North Korea into political reflexes likely to serve their causes. .... continues

That is something very much like brainwashing happens in Nineteen Eighty-Four, in lengthy and terrifying detail, to its hero, Winston Smith, did not surprise those readers determined to take the novel as a simple condemnation of Stalinist atrocity. ${ }^{7}$

This intention of the English writer was then expressed through his warning owing to what he experimented over the years from one country to another as it is depicted in each of his works. Meanwhile, Nineteen Eighty-Four has brought aid and comfort to generations of anti-communist ideologues with Pavlovian-response issues of their own, Orwell's politics were not only of the Left, but to the left of Left. In his book entitled Homage to Catalona, he proved that he had gone to Spain in 1937to fight against Franco and his Nazi-supported fascists, and there had quickly learned the difference between real and phony anti-fascism. 'The Spanish war and other events in 1936-7,' he wrote ten years later, turned the scale and thereafter I knew where I Stood. In these works, we realize that every line of serious work that he has written, directly or indirectly, against totalitarianism and for democratic socialism, is to warn the whole world about the danger a system of management or of ruling.

Orwell witnessed the hard conditions which people are involved in and could remember what happened even years had passed. Orwell thought of himself as a member of the 'dissident Left', as distinguished from the official Left, meaning basically the British Labour Party, most of which he had come, well before the second World War with many consequences due to the period it lasted, without forgetting the last two important events at the end of 1945 related to the launching of the atomic bomb in Hiroshima and Nagazaki respectively the sixth and the nineth of the same year. More or less consciously, he found an analogy between British Labour and the communist Party under Stalin both, he felt, was movements professing to fight for the working classes against capitalism but in reality concerned only with establishing and perpetuating their own power. Everything happened as if only one powerful person behaves on behalf of the other, also, there is a kind of exercise of authority by the superior over the weak the inferior, and then power is abused. Yet, the authority should be proved as in the words of Peter Drucker according to his point of view on the question of management to manage is a task, it is a discipline, it is also people, furthermore he says it is to exercise authority. Whatever the way authority could be used, it is compulsory to avoid what Séidou Badianemphasizes our attention on as far his novel Sous l' Orage is concerned:

Un chef qui fait trembler est comme une grosse pierre qui barre une piste, les voyageurs l'évitent, la contourne puis un jour ils s'apercoivent que le chemin serait moins long s'il n'y avait pas cette pierre, alors ils viennent en grand nombre et la déplacent, la force ne crée pas un chef mais un adversaire à abattre

\footnotetext{
${ }^{6}$ Thomas Pynchon: An Introduction to NineteenEighty-Four, LondonPenguin books, 1949.

${ }^{7}$ Thomas Pynchon: An Introduction to NineteenEighty-Four, LondonPenguin books, 1949.
} 
A chief who terrifies is like a big stone which closes a way. The travelers avoid it, going round and then, they realise that the way would be less long if there were no stone on it. Therefore, numerous are they to come and remove it. Force doesn't create a chief but adversity to be ended up. ${ }^{8}$

In this regard, the presentation of Nineteen Eighty-Four can be formulated into the description and social evolution of Winston and Julia; In fact, the story of Winston Smith Smith presents the world in the year 1984 after a global atomic war, via the perception of life in Airstrip One, a province of Oceanoia, one of the world's three super States; his intellectual rebellion against the Party and illicit romance with Juliua; and his consequent imprisonment.

Winston is an intellectual, a member a member of the Outer Party (middle class). Orwell detected a totalitarian government in Nineteen Eighty-Four that controlled thought by controlling language, making certain ideas literally unthinkable. Several words and phrases from Nineteen Eighty-Four have entered popular language. Big Brother's totalitarian government is the severe of any revolutionary or opposition force. This system is demonstrated through totalitarianism, psychological manipulation, physical control of information and history. Therefore, to come out to the issue, Nineteen Eighty Four as a political novel is written with the purpose of warning readers in the West of the dangers of a totalitarian government, as ha has witnessed firsthand the horrific lengths to which totalitarian governments in Spain and Russia would go in order to sustain and increase their power. Now, those of fascistic disposition, or merely those among us who remain all too ready to justify any government action, whether right or wrong will immediately point out that this is pre-war thinking, and that the moment enemy bombs begin to fall on one's homeland, altering the scape and producing casualties among friends and neighbours, all this sort of thing, really, becomes irrelevant, if not indeed subversive. With the homeland in danger, strong leadership and effective measures become of the essence, and if you want to call that fascism, very well, call it whatever you please, no one is likely to be listening, unless it's for the air raids to be over and the all clear to sound. But the unseemliness of an argument, let alone a prophecy, in the heat of some later emergency, does not necessarily make it wrong. One could certainly argue that Churchill's war cabinet had behaved no differently than a fascist regime, censoring news, controlling wages and prices, restricting travel, subordinating civil liberties to self-defined wartime necessity. But in Europe and America the anticommunism criticism is appreciated in various ways.

\subsection{English Communism in Nineteen Eighty Four}

Also Orwell designed Nineteen Eighty Four to sound the alarm in Western nations still unsure about how to approach the rise of communism. In 1949, the cold war had not yet rooted, many American intellectuals supported communism, and the state of diplomacy between democratic and communist nations was highly ambiguous. It is the time to remark that the Soviet Union was often portrayed in the press as a great moral experiment. Orwell, however, was deeply disturbed by the wide press cruelties and oppressions he observed in communist countries, and seems to have been particularly concerned by the role of technology in enabling oppressive governments to monitor and control their citizens. The masses were only there to be used, for their idealism, their class resentments, their willingness to work cheap, and to be sold out again and again.

Orwell's critique of England's official Left was to undergo some modification in July 1945, when, at the first opportunity they got, the British electorate, by a landslide, threw out their wartime ruler and put in a Labour government, which would remain in power till 1951, beyond what would be left of Orwell's lifetime during which period Labour finally got its chance to reshape British society along socialist lines. Orwell, being a perpetual dissident, must have been delighted to help the party confront its contractions, notably those arising from its wartime acquiescence, a repressive, Tory-led government. Once having enjoyed and exerted that sort of power, how likely would Labour be to choose not to extend its scope, rather than to the ideals of its founders, and go back to fighting on the side of the oppressed? Project this will to power four decades into the future, and you could easily end up with Ingsoc, Oceania and Big Brother.

\footnotetext{
${ }^{8}$ Séidou Badian, In Sous l' Orage Présence Africaine, Paris, 1963, p.108, (our own translation)
} 
Orwell seems to have been particularly annoyed with the widespread allegiance to Stalinism to be observed among the Left, in the face of overwhelming evidence of the evil nature of the regime. 'For somewhat complex reason' he wrote in March 1948, early in the revision of the first draft of Nineteen Eighty-Four, 'nearly the whole of the English Left has been driven to accept the Russian regime as "Socialist", while silently recognizing its spirit and practice quite alien to anything that is meant by "Socialism', in this country. Hence there has arisen a sort of schizophrenic manner of thinking, in which words like "democracy" can bear two irreconcilable meanings, and such things as concentration camps and mass deportations can be right and wrong simultaneously.

The sort of schizophrenic manner of thinking is a source for one of the great achievements of this novel, one which has entered the everyday language of political discourse, the identification and analysis of doublethink. As described in Emmanuel Goldstein's 'The Theory and Practice of Oligarchical Collectivism', a dangerously subversive text is a form of mental discipline whose goal, desirable and necessary to all party members, is to be able to believe two contradictory truths at the same time. This is nothing new, of course. We all do it. In social psychology it has long been known as 'cognitive dissonance'. Others like to call it 'compartmentalization'. Some, famously F. Scott Fitzgerld, have considered it evidence of genius. For Walt Whitman ('Do I contradict myself? Very well, I contradict myself') it was being large and containing multitudes, for Yogi Berra it was coming to a fork in the road and taking it, for Schrödinger's cat, it was the quantum paradox of being alive and dead at the same time.

The idea seems to have presented Orwell with his down dilemma, a kind of meta-doublethink, repelling him with its limitless potential for harm, while at the same fascinating him with its promise of a way to transcend opposites, as if some aberrant form of Zen Buddhism, whose fundamental koans are the three Party slogans 'War is Peace', 'Freedom is Lavery' and Ignorance is Strength' p279 were being applied to evil purposes. Orwell shows the way the communist revolution in Russia is described and the way the government in Nineteen Eighty Four is a material used to produce a political satire and this help people identify the danger of the totalitarian government. Everything happens in Nineteen Eighty Four as a reality, what is entirely the contrary:

Even the names of the four ministries by which we are governed exhibit a sort of impudence in their deliberate reversal of the facts. The ministry of peace concerns itself with war, the ministry of truth concerns with lies, the ministry of of love with torture and the ministry of plenty with starvation. These contradictions are not accidental, nor do they result from ordinary hypocrisy: they are deliberate exercises in doublethink p $195^{10}$

The consummate embodiment of doublethink in this novel is the Inner Party official O'Brien, Winston's seducer and betrayer, protector and destroyer. He believes with utter sincerity in the regime he serves, and yet can impersonate perfectly a devout revolutionary committed to its overthrow. He imagines himself a mere cell of the greater organism of the State, but it is his individuality, compelling and self-contradicting, that we remember. Although a calmly eloquent spokesman for the totalitarian future, O'Brien gradually reveals an unbalanced side, a disengagement from reality that of emerge in its full unpleasantness during the re-education of Winston Smith, in the place of pain and despair known as the Ministry of love.

Doublethink also lies behind the names of the super ministries that run things in Oceania - the Ministry of peace wages war, the Ministry of truth tells lies, the Ministry of love tortures and eventually kills anybody whom it deems a threat.

If this seems unreasonably perverse, recall that in the present -day United States, few have any problem with a war-making apparatus named 'the Department of Defense' any more than we have saying 'Department of Justice' with a straight face, despite well-documented abuses of human and constitutional rights by the most formidable arm, the FBI. Our nominally free news media are required to present 'balance' coverage, in which every 'truth' is immediately neutered by an equal and opposite one. Every day public opinion is the target of rewritten history, official amnesia and outright

${ }^{9}$ George Orwell, Animal Farm , Page 27

${ }^{10}$ George Orwell, Animal Farm , Page 195 


\section{Dr. Ibrahim Yêkini et al.}

lying, all of which is benevolently termed 'spin', as if it were no more harmful than a ride on a merrygo-round. We know better than what they tell us, yet hope otherwise. We believe and doubt at the same time - it seems a condition of political thought in a modern super state to be permanently of at least two minds on most issues. Needless to say, this is of inestimable use to who's in power who wishes to remain there, preferably forever.

Besides the ambivalence within the Left as to Soviet realities, other opportunities for double thing in action arose in the wake of the Second World War. In its moment of euphoria, the winning side was making, in Orwell's view, mistakes as fatal as any made by the Treaty of Versailles after the First World War which began in 1914 and ended in 1918. Despite the most honourable intentions, in practice the present division of spoils among the former Allies carried the potential for fatal mischief. Owell's uneasiness over the 'peace' in fact is one major subtext of Nineteen Eighty-Four.

Orwell wrote to his publisher at the end of 1948, as nearly as we can tell early in the revision phase of the novel to discuss the implications of dividing the world up into 'Zones of Influence" (he thought of it in 1944 as a result of the Teheran Conference).

Well, of course novelists should not be altogether trusted as to the sources of their inspiration. But the imaginative procedure bears looking at. The Teheran Conference was the first Allied summit meeting of the Second World War, taking place late in 1943, with Roosevelt, Churchill and Stalin in attendance. Among the topics they discussed was how, once Nazi Germany was defeated, the Allies would divide it up into zones of occupation. Who and how they would get another issue. In imagining Oceania, Eurasia and Eastasia, Orwell seems to have made a leap in scale from Teherantalks, projecting the occupation of a defeated country into that of a defeated world. Though China had not been included, and the Chinese revolution in 1948 was still in progress, Orwell had been in the Far Eartanf known better than ignore the weight of Eastasia when arranging his own Zones-of-Influence scheme. Geopolitical thinking in those days was enchanted with the World War of British geographer Halfordmackinde, meaning Europe, Asia and Africa considered as a single landmass surrounded by water, 'the pivot of history', whose heartland was Nineteen Eight-Four's 'Eurasia'. 'Who rules the Heartland commands the World-Island commands the pronouncement not lost on Hitler and other theoreticians of real politic.

One of these Mackinderites with connections in intelligence circles was James Burnham, an American ex-Trotskyist who around 1942 had published e provocative analysis of the world crisis then current called The Managerial Revolution, which Orwell discussed later in a lengthy article in 1946.Burnaham, at the time, with England still reeling under Nazi assault and German troops at the outskirts of Moscow, argued that with the conquest of Russia and the global heartland imminent, the future would belong to Hitler. Later in the war, while serving with the OSS, with the Nazis headed for defeat, Burnham changed his mind in a lengthy afterthought, 'Lenin's Heir', in which he now argued that unless the United States did something about it, the future, actually, would belong to Stalin and the soviet system, and not Hitler after all. By this point Orwell, who took Burnham seriously but not uncritically, may have sensed that the man's thinking was sort of on the flighty side - nevertheless taces of Burnham's geopolitics can be found in the tripartite world balance of power of Nineteen Eighty-Four, with Burnham's victorious Japan becoming Estasia Russia, the pivotal heartland, controlling the Eurasian landmass, and the Anglo-American Alliance transmogrifying to Oceania, which is the setting for Nineteen Eighty-Four.

This grouping of Britain and the Unites States in a single bloc, as prophecy, has turned out to be deadon, foreseeing Britain's resistance to integration with the Eurasian landmass as well as her continuing subservience to Yank interests - dollars, for instance, being the monetary unit of Oceania. London is still recognizably the London of the post-war austerity period. From the opening, with its cold plunge directly into the grim April day of Winston Smith's decisive, act of disobedience, the texture of dystopian are unremitting - the uncooperative plumbing, the cigarettes that keep losing their tobacco, the horrible food, though perhaps this was not such an imaginative stretch for anyone who'd have undergone wartime shortages. Nineteen Eighty Four is surely one of the best known novels of the century. It projects a negative utopia or dystopia of a future totalitarian society which uses terror, surveillance and a repressive bureaucracy to exert total power over the individual. Indeed, from the 1940s to the present, the George Orwell's novel Nineteen Eighty Four has been used in the cold war against communism. During the time when much of the western world was lauding communism countries as a step towards human progress in the development of equity in government, Orwell 
clearly and definitively spoke out against the practice. So in Nineteen Eighty Four, Orwell presents a dystopia or in other words, the perfect totalitarian State. In composing this novel, Orwell gave the world a glimpse of what the embrace of communism might lead to if allows to proceed unchecked. The Party is unflawed in its universal control over society, as evidenced by its ability to break even an independent thinker such as Winston, and has mastered every aspect of psychological control, largely through utilising technological developments ( allowing for inventions such as telescreen) to their advantage. In ending the novel with Winston defeated in every sense of the term, Orwell clearly suggests that there is no hope for quelling the expansion or growth of such a perfectly established regime. And more importantly, Orwell warns that at the time, this outcome was within the realm of possibility as long as the world supported and embraced communism. Winston's reflexion in the novel give Orwell the opportunity to discuss the deeper issues at work, issues such as the mind control, through propaganda and technology, and the total manipulation through conditioning and rewriting of history.

\subsection{Nineteen Eighty-Four as a Prediction of Political System of the Twentieth Century}

Prophecy and prediction are not quite the same, and it would ill serve writer and reader alike to confuse them in Orwell's case. There is a game some critics like to play, worth maybe a minute and a half of diversion, in which one makes lists of what Orwell did and didn't get right. Looking around us at the present moment, for example, we note the popularity of helicopters as a resource of 'law enforcement', familiar to us form countless televised 'crime dramas', themselves forms of social control and for that mate rat the ubiquity of television itself. The two-way telescreen bears a close enough resemblance to flat plasma screens linked to 'interactive' cable systems. News is whatever the government says it is, surveillance of ordinary citizens has enteressed the main stream of police activity, reasonable search and seizure and so forth. It is observed that the Government has turned into Big Brother, just like Orwell predicted and as in his words Big Brother is watching you.

Well, specific predictions are only details, after all. What is perhaps more important, indeed necessary is to be able to see deeper than most of us into the human soul. Orwell in 1948 understood that despite the Axis defeat, the will to fascism had not gone away, that far from having seen its day it had perhaps not yet even come into its own, the corruption of spirit, the irresistible human addiction to power, were already long in place, all well-known aspects of the Third Reich and USSR, even the British Labour Party, like first drafts of a terrible future. What could prevent the same thing from happening to Britain and the Unites States? Moral superiority? Good intentions? Clean living? Also emphasizing on the question of power and corruption, Lord Acton, the British writer is right when he points out that power corrupts, absolute power corrupts absolutely.

What has steadily, insidiously, improved since then, of course, making humanist arguments almost irrelevant is the technology. We must not be too distracted by the clunkiness of the means of surveillance current in Winston Smith's era. In Nineteen Eighty Four's novel, after all, the integrated circuit chip was less than a decade old, and almost embarrassingly primitive next to the wonders of computer technology, most notably the Internet, a development the promises social control on a scale those quaint old twentieth-century tyrants with their goofy moustaches could only dream about.

\subsection{Anti-Semitism Depiction in Nineteen Eighty-Four}

Orwell did not foresee such exotic developments as the religious wars with which we have become all too familiar, involving various sorts of fundamentalism. Religious fanaticism is in fact strangely absent from Oceania, except in the form of devotion to the Party. Big Brother's regime exhibits all the elements of fascism, the single charismatic dictator, the total control of behaviour, the absolute subordination of the individual to the collective, except for racial hostility, in particular anti-Semitism, which was such a prominent feature of fascism as Orwell knew it. The only Jewish character in the novel is Emmanuel Goldstein, and maybe only because his original Leon Trotsky, was Jewish too. And he remains an offstage presence whose real function in Nineteen Eighty-Four is to provide an expository voice.

Recently, much has been made of Orwell's attitude toward Jews, some commentators even going so far as to call an anti-Semitic. If one looks in his writing of the time for overt references, one finds relatively little Jewish matters did not seem to command much of his attention. The evidence indicates either the enormity of what had happened in the camps or a failure at some level to appreciate its full significance. There is some left reticence, as if with so many other deep issues to worry about, Orwell 
would have preferred that the world not be presented the added inconvenience of having to think much about holocaust. The novel may even have his way of redefining a world in which the holocaust did not happen.

As close as Nineteen Eighty-Four gets to an anti-Semitic moment in the ritual practice of Two Minutes Hate, presented quite early, almost as a plot device for introducing Julia and O'Brien, the other two major characters. But the exhibition of anti-Goldsteinism described here with such toxic immediacy is never generalized into anything racial. The strategy of pitting race against race does not seem to be found in the party's tool kit. Nor is there any racial discrimination,' as Emmanuel Goldstein himself confirms, in the book, Jews, Negroes, South Americans of pure Indian blood are to be found in the highest ranks of the Party. As nearly as one can tell, Orwell considered anti-Semitism one variant of the great modern disease of nationalism, and British anti-Semitism in particular as another form of British stupidity. He may have believed that by the time of tripartite coalescence of the world he imagined for Nineteen Eighty-Four, the European nationalisms he was used to somehow no longer exist, perhaps because nations, and hence nationalities, would have be abolished and absorbed into more collective identities. Amid the novel's general pessimism, this might strike us, knowing what we know today, as an unwarrantedly chirpy analysis. The hatred Orwell never found much worse than ridiculous have determined too much history since 1945 to be dismissed quite so easily.

\section{CONClusion}

This article has demonstrated that writers played an important role in people's emancipation inthe twentieth century in Europe. English writers broke with the traditional issues of the Victorian novel related to the storytelling and entertainment and focussed on individuals and their daily dilemmas, developing propaganda and social concerns. Prominent among the twentieth century writers, David Herbert Lawrence abundantly uses Oedipus complex to reveal the social discomfort many British citizens are caught in their dissatisfaction with social norms and principles.

\section{REFERENCES}

[1] Crosland Rachel, Analysis of Virginia Woolf and the Study of Nature. Cambridge of St. John's College, Oxford. 2011.

[2] Freud, S. The Ego and the Id. The Hogarth Press Ltd. London. 1949

[3] Lawrence D.H. Sons and lovers.1913.New York: Barnes and Noble, 2003.

[4] Lodge, David. The Modes of Modern Writing: Metaphor, Metonymy, and Typology of Modern Literature. London: Edward Arnold, 1977.

[5] Wells G. P. The Science of Life. 1931 New York: Barnes and Noble, 2007.

[6] Williams, Raymond. The English Novel from Dickens to Lawrence. New York: Oxford UP, 1991

[7] Orwell, George. Nineteen Eighty Four. Penguin Books first published in 1949 by Martin Secker and Warburg Ltd

[8] Orwell, George. Animal Farm: A fairy story. London: Penguin Books. First published 1945.

[9] Séidou Badian, Sous l'Orage Présence Africaine, Paris, 1963, p.108.

[10] Kendra cherry. What is an Oedipus complex? Web. verywzll, July 2016. 